University of Nebraska - Lincoln

DigitalCommons@University of Nebraska - Lincoln

Papers in Ornithology

Papers in the Biological Sciences

1959

\title{
Variability in the Electrophoretic Patterns of Avian Serum Proteins
}

Charles G. Sibley

Paul A. Johnsgard

University of Nebraska-Lincoln, pajohnsgard@gmail.com

Follow this and additional works at: https://digitalcommons.unl.edu/biosciornithology

Part of the Ornithology Commons

Sibley, Charles G. and Johnsgard, Paul A., "Variability in the Electrophoretic Patterns of Avian Serum Proteins" (1959). Papers in Ornithology. 69.

https://digitalcommons.unl.edu/biosciornithology/69

This Article is brought to you for free and open access by the Papers in the Biological Sciences at DigitalCommons@University of Nebraska - Lincoln. It has been accepted for inclusion in Papers in Ornithology by an authorized administrator of DigitalCommons@University of Nebraska - Lincoln. 


\section{VARIABILITY IN THE ELECTROPHORETIC PATTERNS OF AVIAN SERUM PROTEINS}

By CHARLES G. SIBLEY and PAUL A. JOHNSGARD

It has been known for more than 50 years that particular proteins characterize every species of plant and animal and that phylogenetic relationships are reflected in protein structure. The first application of this fact to taxonomic studies was by Nuttall (1901; 1904) who used the precipitin reaction of immune sera to test degrees of relationship in over 500 species of animals. With refinements in technique have come many more serological studies and the results have justified the statement by Landsteiner (1945) that "chemical differences parallel the variation in structure" and hence are useful in classification.

The literature on serology is extensive but it has been summarized in the book by Landsteiner (1945) and the reviews by Boyden $(1942 ; 1953)$. Some of the more recent papers are cited by Stallcup (1954), and Pauly and Wolfe (1957).

The development of other methods for protein characterization has suggested that these too might be applied to systematics. Soon after Tiselius (1937) described his apparatus for the electrophoretic separation of colloidal mixtures Landsteiner, Longsworth, and van der Scheer (1938) used it to compare the egg albumins and hemoglobins of five species of birds. Within the next few years there followed the studies by Moore (1945), Deutsch and Goodloe (1945), and Deutsch and McShan (1949). These authors investigated the plasma proteins of several species of reptiles, amphibians, fish, birds, mammals, and some invertebrates. They showed that electrophoresis could detect the species specific qualities of proteins and that similarity in proteins paralleled evolutionary relationships. With the development of filter paper electrophoresis the procedure has been simplified and the study of Dessauer and Fox (1956) on the plasma proteins of more than 100 species and subspecies of reptiles and amphibians has been the most extensive to date. Others who have used paper electrophoresis include Zweig and Crenshaw (1957) who found specific characters in the serum proteins of turtles of the genus Pseudemys, and Starr and Fosberg (1958) who published the serum protein patterns of several species of sharks. Woods et al. (1958) used starch gel electrophoresis in a study of the sera of 19 species of invertebrates.

The egg white proteins of birds have also been shown to be species specific and to produce excellent electrophoretic profiles. The papers by Bain and Deutsch (1947) and McCabe and Deutsch (1952) are the principal ones to date. The latter reported on 37 species of birds and concluded that the method was applicable to taxonomic problems. Sibley has used paper electrophoresis in a study of the egg white proteins of more than 300 species and has found the conclusions of McCabe and Deutsch fully justified.

In 1956, when the senior author began the study described here, the purpose was to determine the uses and limitations of paper electrophoresis in avian taxonomy. Blood serum, rather than egg white, was chosen because of the relatively greater ease of obtaining material. The egg white studies mentioned above were initiated after the work reported here had been completed.

\section{METHODS AND MATERIALS}

The first studies were made on readily available species including several breeds of Domestic Fowl (Gallus gallus), Ring-necked Pheasant (Phasianus colchicus), Mallard (Anas platyrhynchos), Black Duck (Anas rubripes), Pintail (Anas acuta), and Redhead Duck (Aythya americana). A few other species were also studied including Red-tailed Hawk (Buteo jamaicensis), Rock Dove (Columba livia), Common Crow (Corvus 
brachyrhynchos), European Starling (Sturnus vulgaris), Tree Sparrow (Spizella arborea) and Slate-colored Junco (Junco hyemalis).

The larger species were bled from the wing vein using a hypodermic syringe and three to five milliliters of blood were extracted. The smaller species were bled from the jugular vein or by heart puncture and smaller quantities of blood were usually obtained. The sample was allowed to clot under refrigeration for from two to four hours, then it was centrifuged for 15 minutes at approximately $4000 \mathrm{rpm}$.

The electrophoretic apparatus used was manufactured by the Spince Division of Beckman Instruments, Inc., and consisted of a standard "Durrum" cell (Model R), a constant current power supply ("Duostat") and associated equipment for dyeing, rinsing and fixing the strips. The buffer used was the Spinco B-2, consisting of a mixture of diethyl barbituric acid and sodium diethyl barbiturate to provide a liter of solution with a $\mathrm{pH}$ of 8.6 and an ionic strength of 0.075 . All separations were made at a constant current of eight milliamperes per cell during a period of 16 hours at room temperature. Each cell contains eight strips $30 \mathrm{~mm}$. in width.

Ten microliters of serum were placed on each of seven strips and the eighth received the same amount of a standard solution of bovine serum albumin as a control. Following the 16-hour separation the strips were dried in an oven at $110^{\circ}$ to $120^{\circ} \mathrm{C}$., dyed in bromphenol blue (six hours), then rinsed, fixed and dried according to the procedure specified by the manufacturer (Spinco Procedure A). The resulting dyed strips were analyzed by the Spinco Analytrol (Model RB), which "translates" the protein components into a pen-drawn curve, with the height of the curve being in direct proportion to the protein density at any given point. This apparatus has the additional advantage of providing an automatic integration of the area subtended by this curve, thus allowing a fairly easy calculation of relative protein densities for any portion of the profile. For purposes of quantitative analysis, the protein protile was divided into centimeter units measured in both directions from the point of application, and the mean percentage of each centimeter unit was calculated for a given sample. At the somewhat alkaline $\mathrm{pH}$ used, most blood serum proteins exhibited anodal migration. Under the existing standardized conditions, identical proteins will occur at the same location on the strips and differences among strips must be interpreted as resulting from the presence of different proteins, or from differences in concentrations of the same proteins. No correction for the differential staining of albumin and globulins, as reported by Jencks, Jetton, and Durrum (1955), was made. The profiles presented here represent typical curves obtained for each sample group, and the superimposed histograms indicate the percentage of total protein found in each centimeter unit.

For comparative purposes a "Difference Index" (abbreviated "D.I.") was devised, in the hope of providing an objective value for the protein profile differences existing between two sets of protein percentage data. This index was obtained by subtracting mean protein percentages for each corresponding centimeter unit on both sides of the point of application, and totalling the differences for all centimeter units, without regard for the positive or negative value of these differences. The resulting single number is proportional to the difference between two compared profiles, but its validity is limited to comparisons between geometrically similar curves and thus only closely related curves can be validly compared with this method.

\section{RESULTS}

Ring-necked Pheasant (Phasianus colchicus)

The largest series of samples from a single species was obtained from pen-reared Ring-necked Pheasants provided by the Ithaca Game Farm of the New York State 
Conservation Department. Males ranging in age from about two months to one year and females ranging from two months to two years of age were sampled. These data will be discussed according to age and sex groups.

Eight-to-sixteen-week-old males and females.-Twenty samples from 18 juvenile female pheasants, and 14 samples from 12 juvenile males were obtained from July 2 to 10 ,
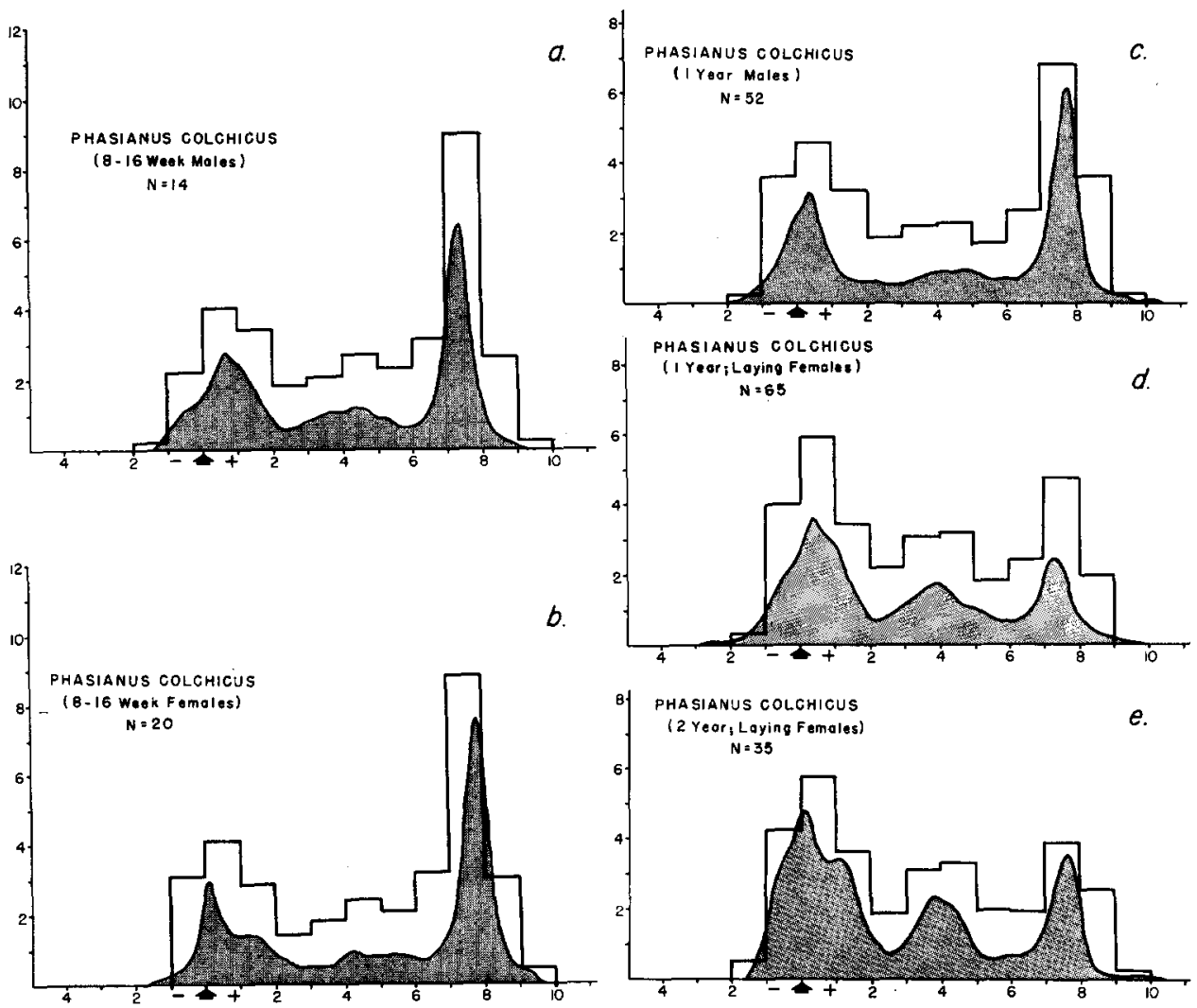

Fig. 1. Typical blood serum protein profiles and protein distribution histograms of Ring-necked Pheasants: $a, b$, juvenile males and females; $c, d$, one-year-old males and females; $e$, twoyear-old females. Mean percentage of total protein per centimeter is indicated by histograms; each centimeter of height equals three per cent of total protein.

1957. Sexual differences in the protein profiles of this age group are negligible (fig. $1 a, b$ ), and a Difference Index value between the sexes of 10.82 was obtained. This age class is characterized by the smallest globulin concentration observed in any of the age and sex groups tested, accompanied by a correspondingly high value ( 26 per cent at centimeter 8 ) in the albumin portion of the profile. The coefficient of variability for protein percentage in anodal centimeter 8 (peak albumin concentration) is 23.06 for males, and 35.37 for females, a value which, although very high, was nevertheless the lowest observed in any age or sex class tested. Coefficients of variability obtained for anodal centimeter 2 (in the beta globulin region) were 27.05 for males and 34.00 for females, which are not especially different from the values obtained for the other groups for this fraction. 
One-year-old males and females.-Sixty samples from 47 one-year-old females and 52 samples from 32 one-year-old males (fig. $1 c, d$ ) were collected from June 3 to 25 , 1957. These females were laying and this factor appeared to be responsible for the relatively large sexual differences in the serum protein profiles observed in this age class. The calculated Difference Index between one-year-old males and females was 25.22. This difference resulted largely from differences in albumin concentration, which was fairly high (20.54 per cent in centimeter 8) in males, and relatively low (14.12 per cent in centimeter 8 ) in females. The coefficient of variability for serum protein percentage in centimeter 8 was 46.34 for males and 57.27 for females, the latter being the highest

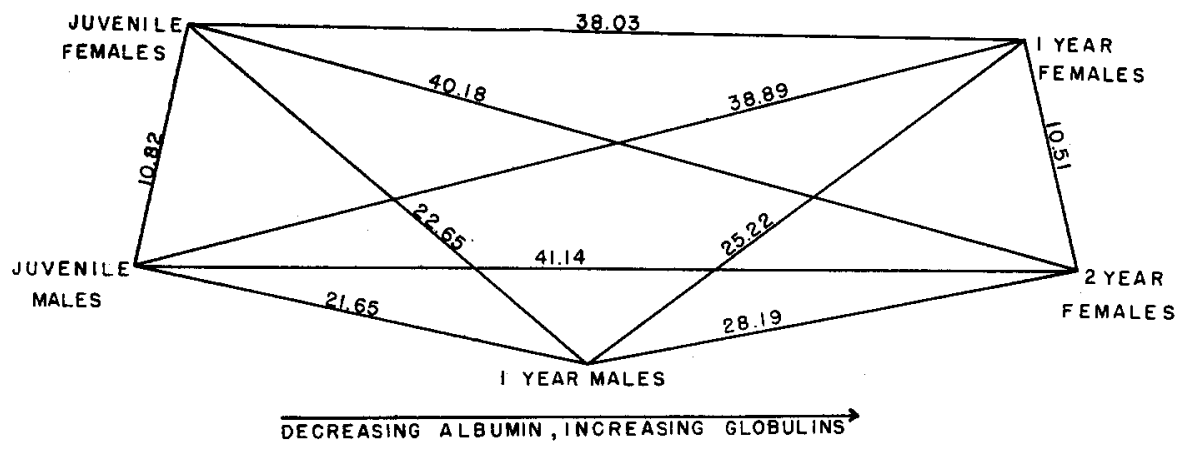

Fig. 2. Diagram showing protein profile relationships among age and sex groups of Ring-necked Pheasants.

variability coefficient obtained in the pheasant groups. Beta globulin coefficients of variability (centimeter 2) were 35.79 for males and 30.25 for females, which also are relatively high values.

Two-year-old females. - Although no two-year-old males were available for sampling, 35 samples from 25 two-year-old female pheasants were obtained (fig. 1e) between June 4 and 20,1957 . These birds, like the one-year-old females, were laying, and the low serum albumin levels ( 11.58 per cent at centimeter 8 ) attest to this fact. These were the lowest albumin levels observed in any pheasant group, but possibly they were not significantly lower than those of the one-year-old females. Conversely, the globulin levels tended to average slightly higher than those of the one-year-old females. Coefficients of variability were 47.54 for centimeter 8 (albumin region) and 18.33 for centimeter 2 (beta globulin region).

Summary of data on Ring-necked Pheasant.-On the basis of Difference Indexes calculated among the age and sex groups of pheasants sampled, a model of protein profile relationships has been constructed (fig. 2). This model indicates the relatively high degree of similarity between the serum protein profiles of juvenile males and females, and between one- and two-year-old females, as well as the general intermediate nature of the one-year-old male samples. These relations exist as a result of the quantitative changes in albumin and globulin levels in the various age and sex groups. Thus globulins tend to increase progressively with age, paralleling increasing antibody formation as each individual is exposed to antigenic substances. Furthermore, females develop lowered albumin levels in the egg-laying period, which results in considerable quantitative variation in the serum protein components during this period. These, however, are only gen- 
eral trends manifested in mean values for large samples, and individual birds under various physiological stresses will show wide deviations from these means.

A few samples of serum from adult Silver (Lophura nycthemera), Reeves (Syrmaticus reevesi), Golden (Chrysolophus pictus), and Lady Amherst (Chrysolophus amherstiae) pheasants were collected on June 25 . The females of these species were laying at the time of sampling, and it is of interest that in all cases the female blood albumin levels were below those of the males, although only one individual of each sex was sampled.

Domestic Fowl and Jungle Fowl (Gallus gallus)

Two breeds of Domestic Fowl and their wild ancestor, the Red Jungle Fowl, were sampled. Fourteen samples from 13 adult male Red Jungle Fowl were obtained on July 18,1957 , and the resulting mean protein profile percentages are shown in figure $3 a$. It will be observed that blood albumin levels in these males averaged somewhat lower (12.40 per cent in centimeter 8) than those of adult male Ring-necked Pheasants (20.54 per cent in centimeter 8), and the globulin levels were correspondingly higher. It is of interest that, except for slight quantitative differences, these two profiles are more similar to one another than either is to the female profile of its own species. Furthermore, serum albumin mobility in the Jungle Fowl is essentially the same as in the pheasant and, as will be seen later, as in practically all birds tested. This is a strikingly different situation from that found in egg white (McCabe and Deutsch, 1952; Sibley, MS), where the mobility of the ovalbumin fraction may vary considerably among related species. This suggests that natural selection has favored a fairly uniform structure for the serum albumin of bird blood, which in view of its function in osmotic regulation would appear to be a reasonable supposition. Common, McKinley, and Maw (1953) observed that the mobility of the albumin fractions of domestic fowl, goose, and turkey ranged from 94 to 98 per cent of that exhibited by human albumin, at $\mathrm{pH}$ 8.6. On the other hand, egg albumin with its task of providing the proteins needed by the developing embryo, would probably be much more subject to selective pressures for species variability.

Comparing the male Jungle Fowl serum protein profile with that of the female (fig. $3 b)$, it is seen that serum albumin levels in the females average somewhat lower (10.05 in centimeter 8) than in males. These birds were occasionally laying but not so regularly as females of domestic breeds such as the Rhode Island Reds and White Leghorns (fig. $3 c, d$ ) sampled. In the case of the Rhode Island Red females, 27 samples of which were obtained from 20 adults on July 11 and 12, average serum albumin levels at anodal centimeter 8 were 7.68 per cent. In all samples obtained on July 17 from 10 laying White Leghorns albumin levels at centimeter 8 averaged only 4.25 per cent. Thus it would appear that birds at maximum laying capacity are capable of being subjected to extremely low blood albumin levels.

\section{Waterfowl}

Forty-nine samples from 49 adult male Pintails were obtained from June 26 to July 5 , 1957. During the same period, 13 samples from 13 adult male Redheads were obtained; these data are presented in figure $4 a, b$. These profiles, although from species usually considered to belong to different tribes or subfamilies, are quite similar, and a Difference Index between them of 18.47 was calculated. The only other species for which sufficient data were obtained to allow comparison is the Mallard. Nineteen samples were analyzed from a single adult male over a period of several months and although they are thus not entirely comparable to data on the Pintails and Redheads, they are of interest. The Mallard serum protein profile (fig. $4 c, d, e$ ) shows little similarity to that of the closely related Pintail (D.I. 33.93) and indeed is much more similar to that of the Redhead 
(D.I. 20.38). It is apparent that taxonomic conclusions based on such evidence would contradict all previously held opinions as to the evolutionary relationships in these birds.

The best evidence to demonstrate seasonal shifts in blood protein concentrations is provided by samples obtained from female Mallards and Black Ducks. Fourteen adult female Mallards were sampled July 1 to 5, 1957, then were kept in captivity until November 13, when seven of these birds were sampled again. At the same time, nine females of the very closely related Black Duck were sampled. The resulting profiles
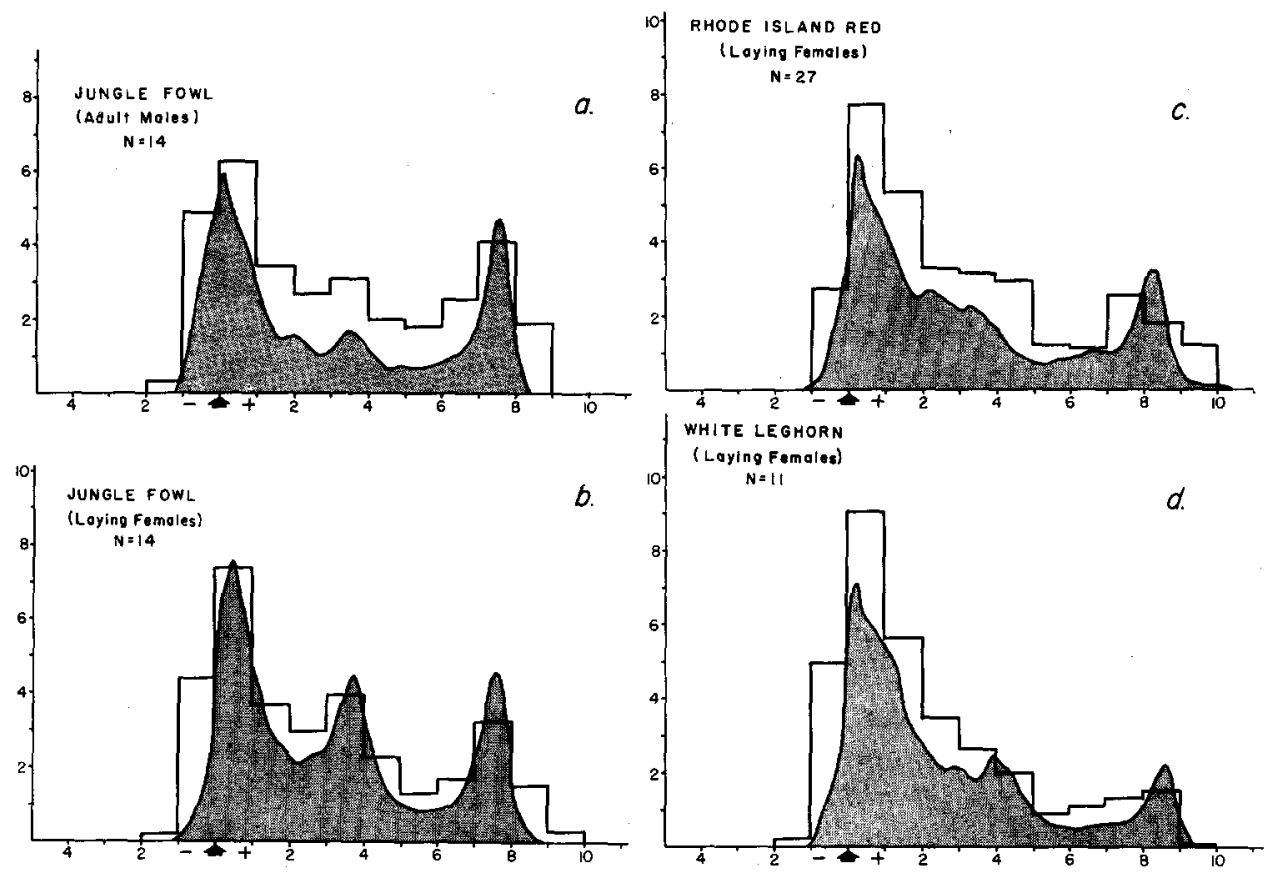

Fig. 3. Typical blood serum protein profiles and protein distribution histograms: $a$, adult male Jungle Fowl; $b$, adult female Jungle Fowl; $c$, adult female Rhode Island Red chickens; $d$, adult female White Leghorn chickens.

(fig. 4f) are of considerable interest, since the profiles obtained from the samples taken in November of the Mallard and the Black Duck are more similar to one another (D.I. 17.74) than are the Mallard profiles obtained in July to those obtained in November (D.I. 40.62), or the Black Duck profiles taken in November to the Mallard profiles taken in July (D.I. 35.20). An additional point is that serum albumin levels of the Mallard in July were considerably higher (29.86 per cent at centimeter 8 ) than either the levels of the Mallard (14.85 per cent) or the Black Duck (14.85 per cent) in November. These Mallards had completed laying in April, thus accounting for the high albumin levels by July, but apparently the birds were subjected to a seasonal shift to lower albumin levels by November.

\section{Other Species}

Various numbers of blood samples from other species of birds were analyzed during the period of study, and although the samples were often too small to have much comparative value, species for which three or more samples were obtained are included (fig. 5) for the sake of completeness and also to indicate the range of serum protein variation. 


\section{COMMENTS ON SOURCES OF INTRASPECIFIC VARIABILITY}

Age.- On the basis of the data on the Ring-necked Pheasant, it may be said that relative blood globulin (including antibody) percentages tend to be lowest in juvenile birds and higher in adults, with a corresponding decrease in relative albumin levels. Brandt, Clegg, and Andrews (1951) observed that both alpha and gamma globulins, as well as total proteins, increase with age in domestic fowl. They observed little difference
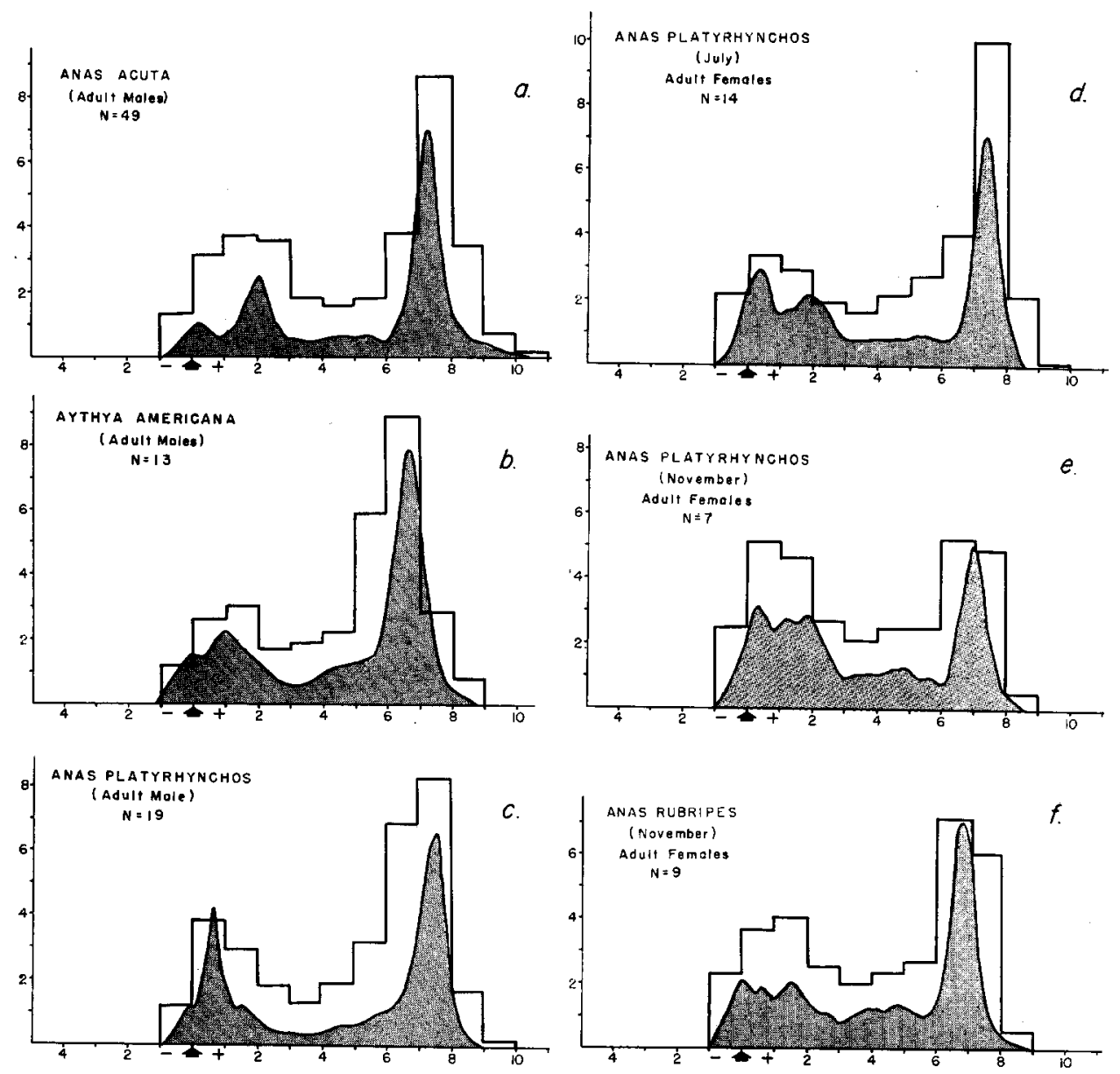

Fig. 4. Typical blood serum protein profiles and protein distribution histograms: $a$, adult male Pintails; $b$, adult male Redheads; $c$, adult male Mallard; $d$, $e$, adult female Mallards; $f$, adult female Black Ducks.

in albumin or beta globulin levels correlated with age, thus possibly the reduced albumin percentages observed by us in adult birds simply reflect the relative increase in globulins with age.

Sex.-Data from Ring-necked Pheasant and Domestic Fowl indicate that blood albumin levels show wide deviations between the sexes during the laying period when those of the female may be greatly reduced below those of males sampled at the same time. Sturkie and Newman (1951) observed similar effects of laying, and found that 
Albumin/Globulin ratios are increased from 0.60 in non-laying birds to from 0.83 to 0.93 in laying females. Males' Albumin/Globulin ratios averaged 0.70, and total protein concentration averaged less than in females. Brandt et al. (op. cit.) found, when using certain buffers, an additional fast-moving component to be present in the sera of laying hens that had earlier been demonstrated by Deutsch and Goodloe (1945). Veronal buffer did not show it, since apparently the albumin fraction obscured it, and this possibly
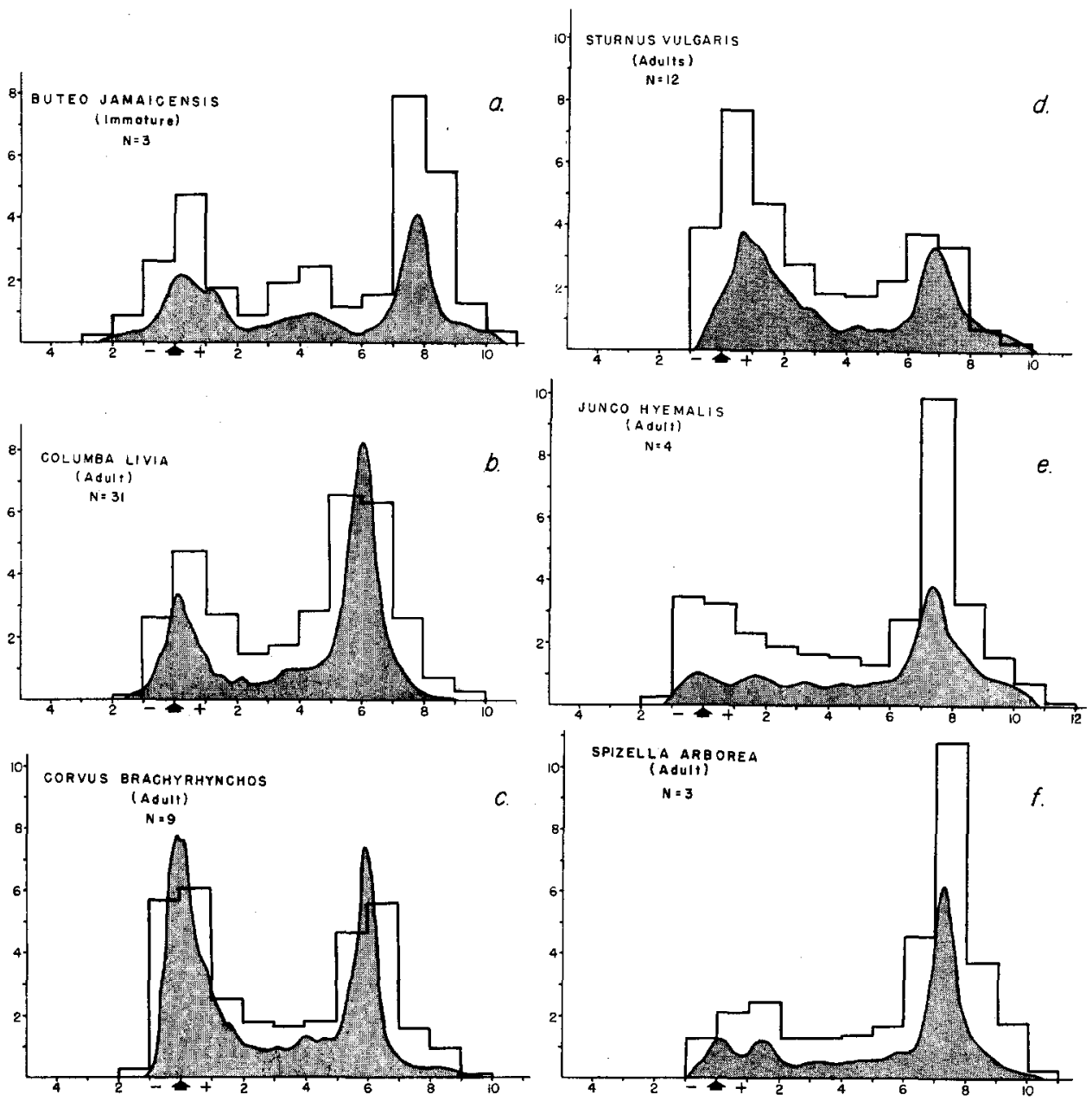

Fig. 5. Typical blood serum protein profiles and protein distribution histograms: $a$, adult Redtailed Hawk; $b$, adult Rock Dove; $c$, adult Common Crow; $d$, adult European Starling; $e$, adult Slate-colored Junco; $f$, adult Tree Sparrow.

explains why our data do not exhibit this extra component. This extra fraction, and the higher globulin levels typical of laying females, were obtained by Clegg et al. (1951) in cockerels and a two-year-old male by the implanting of diethylstilbestrol pellets.

Season.-Results of sampling from Mallards during July and November indicate considerable quantitative changes in serum profiles that apparently are attributable to seasonal variation. 
Pathology.-This source of variability was not investigated by us, but a considerable amount of information has accumulated on the subject, particularly in the medical literature. Data from birds are more limited, but Goldstein and Scott (1956) observed that a decrease in total protein, particularly in the albumin fraction, occurred in chicks of Domestic Fowl with exudative diathesis, and Sanders, Huddleson, and Schaible (1944) observed a decrease in albumin and an increase in alpha globulin levels in Domestic Fowl afflicted with leucosis. They also observed a new component, closely related to gamma globulin, in several forms of this disease. Wall and Schlumberger (1957) found a great increase in the second-most mobile plasma component of the Grass Parakeet (Melopsitticus undulatus) in birds with tumors. Mammals also exhibit major quantitative changes in serum proteins when affected by disease and parasites (Gleason and Friedberg, 1953; Luetscher, 1947). The literature on human pathology has been summarized by Sunderman and Sunderman (1957) and by Jencks, Smith, and Durrum (1956). The former investigators analyzed the serum proteins from 183 patients affected by 21 categories of disease, and they observed that the most frequent deviations from normal sera involved a decrease in albumin and total protein, and an increase in gamma globulin, and, less frequently, alpha 2 globulin levels. Jencks et al. (op. cit.) also observed that infections and pathological conditions were normally accompanied by decreased serum albumin and increased globulins; only rarely did they find the opposite true.

Individual variation.-Even by obtaining large samples of healthy birds of the same age and sex over a short period of time, such large coefficients of variability in quantitative measurements were found as to make it difficult to determine the species-specific characteristics of avian blood serum for taxonomic purposes. This high degree of individual variability in healthy birds was also observed by Wall and Schlumberger (1957).

\section{CONCLUSIONS}

If reliable quantitative measurements of avian sera are desired, sample size must be large, the birds must be healthy, and they must be separated by age and sex, just as in studies of morphological characters.

Quantitative characteristics in avian sera are less reliable than qualitative ones, thus more weight should be given to the latter if comparative studies are undertaken.

Blood serum profiles of different species of birds tend to be more alike in their qualitative composition than are egg albumen profiles, thus serum provides fewer sources of qualitative specific variation upon which to base taxonomic decisions than does egg white.

\section{SUMMARY}

The procedure and methods used in the electrophoretic separation of over 400 samples of avian serum proteins are presented. Data from Ring-necked Pheasants, Domestic Fowl and several species of waterfowl indicate that the serum proteins vary quantitatively with age, sex, and reproductive condition. Variation associated with disease and nutritional levels is known from other sources.

It is concluded that if avian serum proteins are to be utilized in taxonomy the investigator must use a large number of samples and the birds must be healthy and separated by age and sex classes.

\section{ACKNOWLEDGMENTS}

We are indebted for assistance with the laboratory work to Aileen Merriam, Elizabeth Hollister, and Philippa Claude. The National Science Foundation has supported this work (NSF G-1832 and G-4562) and also that on the egg white proteins. The New York State College of Agriculture at Cornell University has provided facilities and 
equipment. For advice and other assistance we are grateful to Walter L. Nelson, A. L. Neal, Jack Goldstein, J. H. Bruckner, and Richard Reynolds.

\section{IITERATURE CITED}

Bain, J. A., and Deutsch, H. F.

1947. An electrophoretic study of the egg white proteins of various birds. Jour. Biol. Chem., 171:531-541.

Boyden, A.

1942. Systematic serology: A critical appreciation. Physiol. Zool., 15:109-145.

1953. Fifty years of systematic serology. Syst. Zool., 2:19-30.

Brandt, L. W., Clegg, R. E., and Andrews, A. C.

1951. The effect of age and degree of maturity on the serum proteins of the chicken. Jour. Biol. Chem., 191:105-111.

Clegg, R. E., Sanford, P. E., Hein, R. E., Andrews, A. C., Hughes, J. S., and Mueller, C. D.

1951. Electrophoretic comparisons of the serum proteins of normal and diethylstilbestrol-treated cockerels. Science, 114:437.

Common, R. H., McKinley, W. P., and Maw, W. A.

1953. Filter paper electrophoresis of avian serum proteins. Science, 118:86-89.

Dessauer, H. C., and Fox, W.

1956. Characteristic electrophoretic patterns of plasma proteins of orders of Amphibia and Reptilia. Science, 124:225-226.

Deutsch, H. F., and Goodloe, M. B.

1945. An electrophoretic survey of various animal plasmas. Jour. Biol. Chem., 161:1-20.

Deutsch, H. F., and McShan, W. H.

1949. Biophysical studies of blood plasma proteins. XII. Electrophoretic studies of the blood serum proteins of some lower animals. Jour. Biol. Chem., 180:219-234.

Gleason, T. L., and Friedberg, F.

1953. Filter-paper electrophoresis of serum proteins from small animals. Physiol. Zool., 26:95-100.

Goldstein, J., and Scott, M. L.

1956. An electrophoretic study of exudative diathesis in chicks. Jour. Nutrition, 60:349-360.

Jencks, W. P., Jetton, M. R., and Durrum, E. L. 1955. Paper electrophoresis as a quantitative method. Biochem. Jour., 60:205-215.

Jencks, W. P., Smith, E. R. B., and Durrum, E. L.

1956. The clinical significance of the analysis of serum protein distribution by filter paper electrophoresis. Amer. Jour. Med., 21:387-405.

Landsteiner, $\mathbf{K}$.

1945. The specificity of serological reactions. Revised ed. (Harvard Univ. Press, Cambridge).

Landsteiner, K., Longsworth, L. G., and van der Scheer, J. 1938. Electrophoresis experiments with egg albumins and hemoglobins. Science, 88:83-85.

Luetscher, J. A., Jr.

1947. Biological and medical application of electrophoresis. Physiol. Rev., 27:621-642.

McCabe, R. A., and Deutsch, H. F.

1952. The relationships of certain birds as indicated by their egg white proteins. Auk, 69:1-18.

Moore, D. H.

1945. Species differences in serum protein patterns. Jour. Biol. Chem., 161:21-32.

Nuttall, G. H. F.

1901. The new biological test for blood in relation to zoological classification. Proc. Roy. Soc. London, 69:150-153.

1904. Blood immunity and blood relationship (Cambridge Univ. Press, Cambridge [England]).

Pauly, L. K., and Wolfe, H. R.

1957. Serological relationships among members of the order Carnivora. Zoologica, 42:159-166. 
Sanders, E., Huddleson, I. F., and Schaible, P. J.

1944. An electrophoretic study of serum and plasma from normal and leucosis-affected chickens. Jour. Biol. Chem., 155:469-481.

Stallcup, W. B.

1954. Myology and serology of the avian family Fringillidae, a taxonomic study. Univ. Kans. Publ. Mus. Nat. Hist., 8:157-211.

Starr, T. J., and Fosberg, W.

1958. Filter paper electrophoresis of serum proteins from sharks. Copeia, 1957:292-295.

Sturkie, P. D., and Newman, H. J.

1951. Plasma proteins of chickens as influenced by time of laying, ovulation, number of blood samples taken, and plasma volume. Poultry Sci., 30:240.

Sunderman, F. W., Jr., and Sunderman, F. W.

1957. Clinical application of the fractionation of serum proteins by paper electrophoresis. Amer. Jour. Clinical Path., 27:125-158.

Tiselius, A.

1937. A new apparatus for electrophoretic analysis of colloidal mixtures. Trans. Faraday Soc., $33: 524-531$

Wall, R. L., and Schlumberger, H. G.

1957. Electrophoresis of plasma proteins in the parakeet. Science, 125:993-994.

Woods, K. R., Paulsen, E. C., Engle, R. L., Jr., and Pert, J. H.

1958. Starch gel electrophoresis of some invertebrate sera. Science, 127:519-520.

Zweig, G., and Crenshaw, J. W.

1957. Differentiation of species by paper electrophoresis of serum proteins of Pseudemys turtles. Science, 126:1065-1067.

Department of Conservation, Cornell University, Ithaca, New York, September 4, 1958. 